\section{DIGITAL COMMONS \\ @ UNIVERSITY OF SOUTH FLORIDA}

\section{ABO: Interactive Journal for Women in the Arts, 1640-1830}

Volume 4

Issue 1 Volume 4.1 (Spring 2014)

Article 6

2014

\title{
Review of Carol Stewart (ed.), The Rash Resolve and Life's Progress
}

Sarah R. Creel

Simon Fraser University, screel@sfu.ca

Follow this and additional works at: https://digitalcommons.usf.edu/abo

Part of the Dramatic Literature, Criticism and Theory Commons, Educational Methods Commons, Feminist, Gender, and Sexuality Studies Commons, and the Literature in English, British Isles Commons

\section{Recommended Citation}

Creel, Sarah R. (2014) "Review of Carol Stewart (ed.), The Rash Resolve and Life's Progress," ABO:

Interactive Journal for Women in the Arts, 1640-1830: Vol.4: Iss.1, Article 6.

http://dx.doi.org/10.5038/2157-7129.4.1.6

Available at: https://digitalcommons.usf.edu/abo/vol4/iss1/6

This Reviews is brought to you for free and open access by Digital Commons @ University of South Florida. It has been accepted for inclusion in ABO: Interactive Journal for Women in the Arts, 1640-1830 by an authorized administrator of Digital Commons @ University of South Florida. For more information, please contact digitalcommons@usf.edu. 


\title{
Review of Carol Stewart (ed.), The Rash Resolve and Life's Progress
}

\begin{abstract}
This review gives an overview of Carol Stewart's edition of Eliza Haywood's The Rash Resolve and Life's Progress. Providing a modern edition of these texts in print for the first time, Stewart's edition brings the two novels to life with careful attention to historical and contextual details.
\end{abstract}

\section{Keywords}

Eliza Haywood, female authorship, amatory fiction, didactic fiction

Creative Commons License cc) (1) $\odot$

This work is licensed under a Creative Commons Attribution-No Derivative Works 3.0 License. 
Haywood, Eliza. The Rash Resolve and Life's Progress. Ed. Carol Stewart. London: Pickering \& Chatto, 2013. 240pp. ISBN-13: 978-1848933361.

Reviewed by Sarah Creel
Simon Fraser University

With the publication of Kathryn R. King's A Political Biography of Eliza Haywood (Pickering \& Chatto, 2012), the first biography of Eliza Haywood in almost one hundred years, the field of Haywood studies has entered a new phase. A renewed interest in the contextualization of Haywood's work in order to learn more about her life and illustrious career has been called for, and it is exciting to see the further fruits of such a call to action. Carol Stewart's edition of Eliza Haywood's The Rash Resolve (1724) and Life's Progress (1748) is an important example. While editors of Haywood's work, such as David Oakleaf, Alexander Pettit, Margaret Case Croskery, Anna Patchias, and Catherine Ingrassia, have offered readers modern editions of her work, Stewart's edition brings together two of Haywood's novels - one early and one late - in an effort to "further the appreciation of Eliza Haywood as both a significant practitioner of the novel as a genre, and a commentator on, and creator of, her times" (xix). Stewart's reading of the two novels together succeeds in reading Haywood's work and career as fully engaged in the intellectual and cultural currents of the day. Neither of these works has been published in a critical edition, and Stewart's edition, published under the auspices of the Chawton House Library Series, brings the two novels to life with careful attention to historical and contextual details-details that allow the reader a more complete glimpse into the life and times of Eliza Haywood.

The pairing of The Rash Resolve and Life's Progress seems to be a calculated effort to bridge the gap between the portrayal of Haywood as the "Great Arbitress of Passion" and the later, more didactic writer of works such as The Female Spectator. In her introduction, Stewart notes that "both [novels] exemplify "the danger of giving way to passion"" (xi), and the modern reader is left to make the connection between Haywood's early and late fiction and associate it with more of a gradual progression than a sharply defined dichotomy. Stewart explains that both novels have a similar plot structure: the heroine of The Rash Resolve, Emanuella, gives way to her sexual passions, bears an illegitimate child (after abandonment by her lover, Emilius), and then dies. The hero of Life's Progress through the Passions, Natura, similarly gives in to sexual passions (although his misadventures as a male protagonist are notably different from Emanuella's), is cuckolded by his own brother, and is dead by the end of the novel (xi). The similar courses of Emanuella's and Natura's lives are, in true Haywood style, inflected with many a heaving bosom and jilted lover, and garden scenes of sexual intrigue abound. It would be easy to dismiss these novels for their romantic tendencies alone. What Stewart's editing and pairing of these texts reveals, however, is that they are about much more than "warm scenes." Categorizing the works as either titillating or cautionary, to use Stewart's phrasing, does not do justice to their psychological depth or historical roots (xi-xii).

What does do justice to these two works is an exploration of the historical context in which Haywood was writing at the time of the novels' respective publications. Heavily relying on King's contextualization of Haywood's involvement in the Hillarian group in the 1720s, Stewart shows the reader how The Rash Resolve is intricately tied to the coterie group surrounding Aaron 
Hill and how Richard Savage's commendatory poem at the beginning of the novel (which Stewart includes in the edition) sheds light on the complicated relationship between Haywood, Martha Fowke Sansom, and Savage himself. Stewart continues her project of historical contextualization with an exploration of the similarities between Life's Progress and Henry Fielding's Joseph Andrews (1742). She acknowledges Haywood's debt to Fielding by showing how Haywood's moral commentary in Life's Progress follows Fielding's assertion that novels would benefit from a more natural than fantastical style (xvii). This progression of moral commentary can clearly be seen when moving from The Rash Resolve to Life's Progress. Haywood gives very little outright commentary regarding Emanuella's plight in The Rash Resolve, but in Life's Progress, "Haywood reflects on the actions of her characters to a much greater extent than she had done before" (xvii). Where Emanuella is very much a fantastical romantic character (she is the beautiful and exotic daughter of a Spanish nobleman), Natura is an actual 'test case for the proposition that the passions are 'sole authors of all human actions,' and that the passions cancel one another out" (xvii). Further to this, the juxtaposition of the two novels reveals much about how Haywood views the human condition. With Emanuella, she shows us a woman whose beauty does not cover all her faults and whose deep love for her child, Victorinus, allows her to defy eighteenth-century convention and keep her beloved child with her. With Natura, we are given the male perspective, and as with Emanuella, Haywood details his exploits but does not offer judgment. Reading these two novels together heightens our understanding of Haywood's reluctance to judge and her deliberate ambiguity regarding her characters' moral choices. As readers can see from such a pairing of the two novels, allowing for the novels to fall less absolutely on either side of the amatory/didactic divide reveals a more nuanced interpretation of Haywood's canon and allows us to explore the themes that cross this increasingly untenable divide.

The novels themselves are carefully edited and offer students of Haywood a selected bibliography of both primary and secondary Haywood sources and a thorough series of editorial notes to help provide historical context. From a pedagogical perspective, Stewart's editing provides an excellent starting point for undergraduate and advanced academic research. From her thorough explanation of the finer points of the early eighteenth-century marriage contract in both The Rash Resolve and Life's Progress to her explanations of the dense political and religious references that permeate both texts, Stewart carefully maps out the social and political landscape of the eighteenth century for readers. In doing so, Stewart has made Haywood both accessible and deeply interesting for what she can tell us about the political, social, and romantic mores of a century in which these codes are deeply embedded and crucial to everyday life. And, while the edition (available on Pickering and Chatto's website) is costly ( $£ 45$ or $\$ 75$ ), it is a worthwhile addition to any undergraduate syllabus or scholarly collection.

Finally, Stewart's introduction allows that there is much more to be done within Haywood studies to both contextualize Haywood's work and take it seriously (xix). There are a few places where Stewart could have given us more context, and her reliance on King's elucidation of Haywood's relationship with the Hillarians, as well as her exploration of Haywood's dependence on Fielding's ideas about a more natural fiction, could have been condensed in favor of an investigation of the more subversive elements of both texts, such as Haywood's interest in marriage contracts, motherhood, and the potential ill effects of marrying the wrong person. But providing all the context for both novels and/or investigating all of the ways in which Haywood 
exercises her subversive pen is perhaps out of the realm of any one critical edition of Haywood's works. Stewart also asserts that "the fiction Haywood published after 1740 is still not available in modern editions ..." (xix), which means she overlooked Christine Blouch's edition of The History of Miss Betsy Thoughtless (1998), Catherine Ingrassia's edition of Anti-Pamela (2004), and John Richetti's The History of Jemmy and Jenny Jessamy (2005). There is, however, a need for more critical editions of Haywood's later fiction, and more pairings such as The Rash Resolve and Life's Progress would exponentially benefit Haywood studies. Stewart has certainly shown us the benefits of doing so, and she answers her own call to examine the "cognizance of Haywood's range and diversity as well as continuities in her work" (xix). 